\title{
A REVIEW ON MEDICAL ADVANTAGES AND CHEMICAL CONSTITUENTS OF CARICA PAPAYA LINN.
}

\author{
ANJANA GV*, PRIYA D, SRIMATHI R, SHANTHA KUMAR B \\ Department of Pharmaceutical Chemistry, SRM College of Pharmacy, SRM Institute of Science and Technology, Chennai, Tamil Nadu, India. \\ Email: sh631983@gmail.com
}

Received: 30 April 2018, Revised and Accepted: 20 June 2018

\begin{abstract}
Papaya is an evergreen blossoming plant having rich characteristic thing; it is recognized to offer different therapeutic purposes of premium. The normal item is sound and delicious. The entire plant parts such as root, bark, peel, seeds, blooms, leaves, and squash are known to have helpful properties. It is utilized for the treatment of a various infections such as dengue fever, warts, corns, sinuses, skin inflammation, against diabetic, glandular tumors, blood pressure, digestive disorders, constipation, antibacterial, antifertility, anti-HIV, expel worms, invigorate regenerative organs and many, as needs be it can be seen as a nutraceutical. The present review focuses on salient features of nutritional composition, health benefits, medical advantages, and synthetic constituents of papaya.
\end{abstract}

Keyword: Papaya, Dengue fever, Antifungal activity, Anti-HIV activity.

(C) 2018 The Authors. Published by Innovare Academic Sciences Pvt Ltd. This is an open access article under the CC BY license (http://creativecommons. org/licenses/by/4. 0/) DOI: http://dx.doi.org/10.22159/ajpcr.2018.v11i9.26992

\section{INTRODUCTION}

Papaya is developed broadly in all tropical and sub-tropical parts of the world. Papaya has been viewed as a standout among the most profitable tropical organic products that contain beta-carotene, protein, starch, vitamins, and minerals. The papaya is a little, scantily expanded plant, for the most part with a solitary stem developing from 5 to $10 \mathrm{~m}$ tall, leaves are extensive, 0.5 to $0.7 \mathrm{~m}$ in width, significantly palmately lobed, with seven projections. Papaya common items have smooth skin, green, while young turning yellow. The normal Philippine papaya is typically pear shape around 0.1-0.4 m long on maturity [1]. Prepared papaya feels fragile, the skin has yellowish shading, and when opened it has a sensitive orangeyellowish tissue with different minimal dim seeds embedded at the vacant core interest (Fig. 1) [2].

\section{MATERIALS AND METHODS}

\section{Medical advantages of papaya}

Carica papaya leaves extracts for the treatment of dengue fever [3-13]

Ahmad et al. have revealed an examination that the capacity of $C$. papaya departs separate evacuates against dengue fever in Asian Pacific Journal of Tropical Biomedicine. The patient was given $25 \mathrm{ml}$ of leaves extracts twice, day by day for 5 back to back days. It was noted in the report the platelets check, white blood cells and neutrophils lessened from $84.0 \%$ to $46.0 \%$. In this way, the blood tests were rechecked after the association of leaves evacuate, watched that the platelets tally, white blood cells, and neutrophils extended from $46.0 \%$ to $78.3 \%$.

Patil et al. decided the impact of $C$. papaya departs fluid concentrate in expanding the platelet check-in thrombocytopenic rodent display. Watery concentrate of $C$. papaya leaves at a grouping of $400 \mathrm{mg} / \mathrm{kg}$ and $800 \mathrm{mg} / \mathrm{kg}$ were given to cyclophosphamide prompted thrombocytopenic rats for a time of 15 days. Blood was pulled back at different time interims to decide the platelet check. Likewise, the coagulating time was resolved on the $15^{\text {th }}$ day of the examination by slender strategy. C. papaya leaf separate was found to increase the platelet check and furthermore to diminish the coagulating time in rats. The investigation goes for deciding the conceivable impacts of papaya leaves in thrombocytopenia happening in dengue fever.
C. papaya health benefits for blood-related helpful issues [14-16] Ikpeme et al. have reported an examination on the phytochemistry and hematological capacity of the ethanol seed, leaf and mash think of C. papaya in Pakistan Journal of Biological Sciences. In this examination, it was perceived that the phytochemical substance in the seeds, leaf, and mash of $C$. papaya was almost the same however in contrasting degrees. It was likewise watched that the phytochemicals found in C. papaya by and large improved the creation of certain blood parameters in treated albino rats.

Antihyperglycemic effects of ethanol extracts of C. papaya [17-20] Sasidharan et al. have revealed an examination on the phytochemicals in C. papaya may have antihyperglycemic activity in Journal of Natural Product Research. The ethanolic concentrates of $C$. papaya and Pandanus amaryfollius were coordinated to a social occasion of streptozotocin impelled diabetic rats to measure it's against diabetic effects. The examination prescribes that the phytochemical found in C. papaya and P. amaryfollius might be in charge of the counter diabetic well-being benefits.

\section{C. papaya health benefits for digestive disorder [21-25]}

Muss et al. have reported a study on the on the digestive disorders of C. papaya in the journal of Biogenic Amines. Clinical trials including volunteers with constant acid refluxes and dysfunctions in the gastrointestinal tract were given papaya preparation. They were contrasted with a control aggregate given a fake treatment. The examination prescribes that gigantic change in the symptoms of acid reflux and swelling for those under the papaya arranging when stood out from the control gathering. The estimation of the constituents of papaya and its health benefits were discussed in Table 1 and Table. 2 respectively.

\section{Antifungal activity [26-30]}

Chavez-Quintal et al. have revealed an examination on the antifungal activity of ethanolic extracts of $C$. papaya L. cv. Maradol leaves and seeds of discarded ripe and unripe fruit in Indian Journal of Microbiology. Seed extracts indicated inhibition of fungal activity against three phytopathogenic growths: Rhizopus sto lonifer, Fusarium spp. also, 


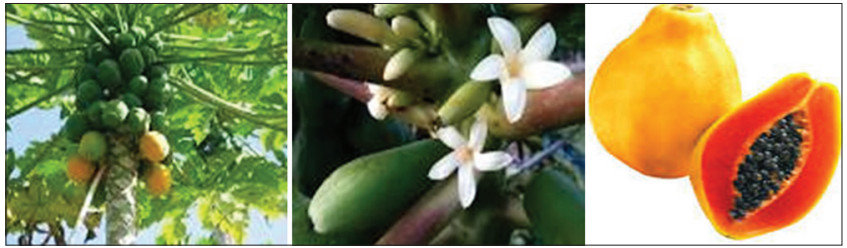

Fig. 1: Carica papaya tree, flower, and ripe fruit

Table 1: Healthful estimation of $100 \mathrm{mg}$ of papaya fruit [77]

\begin{tabular}{lll}
\hline Contents & Green papaya & Ripe papaya \\
\hline Protein & $600 \mathrm{mg}$ & $700 \mathrm{mg}$ \\
Fat & $100 \mathrm{mg}$ & $200 \mathrm{mg}$ \\
Mineral & $500 \mathrm{mg}$ & $500 \mathrm{mg}$ \\
Carbohydrate & $720 \mathrm{mg}$ & $570 \mathrm{mg}$ \\
Fiber & $800 \mathrm{mg}$ & $900 \mathrm{mg}$ \\
Energy & $32 \mathrm{Kcal}$ & $27 \mathrm{Kcal}$ \\
Total carotene & $2740 \mu \mathrm{m}$ & 0 \\
Beta-carotene & $888 \mu \mathrm{m}$ & 0 \\
\hline
\end{tabular}

and Colletotrichum gloeosporioides. Singh and Ali have reported the antifungal movement of the methanolic concentrate of the seeds indicated antifungal action against Aspergillus flavus, Candida albicans, and Penicillium citriniumin Indian diary of pharmaceutical sciences.

\section{Papaya and pregnancy: Safety and side effects [31]}

Adebiyi et al. have reported an investigation done in the Department of Obstetrics and Gynecology in the British Journal of Nutrition. In a lab examine, the effects of prepared papaya blend $(500 \mathrm{ml} / \mathrm{l}$ water) and papaya foul latex to the uteri of pregnant Sprague Dawley rats was diverged from a control aggregate given with water in a manner of speaking. Results have shown that ready papaya has no threatening or perceptible responses, while the rough latex incited convulsive narrowing of the uterine muscles. The examination prescribes that common usage of ready papaya and pregnancy may not represent any noteworthy threat speak to any gigantic hazard. The unripe or semiready papaya could be unsafe in pregnancy.

\section{Antihelminthic and antiamoebic activity of C. papaya seeds} [22,32-34]

Okeniyi et al. have uncovered the ampleness of dried C. papaya seeds against human intestinal parasitosis in the Journal of Medicinal Food. The patient was given either dried seeds of $C$. papaya blended with nectar or nectar alone. $76.7 \%$ of the individuals who were given nectar blended with dried seeds of papaya were cleared of parasites following 7 days while $16.7 \%$ of the individuals who took nectar alone. This examination reasons that air-dried C. papaya seeds are strong in treating human intestinal parasites and without critical side effects.

Anticancer and immunomodulatory activity of C. papaya [35-37] Otsuki et al. have detailed that liquid plan of $C$. papaya leaf extricates have basic improvement inhibitory activity on tumor cell lines in the Journal of Ethnopharmacology. The examination additionally proposes that $C$. papaya leaf concentrate may conceivably give way to the treatment and anticipation of chose human illnesses, for example, growth, different unfavorably susceptible scatters, and may likewise fill in as immune adjuvant for antibody therapy.

Fauziya and Krishnamurthy papaya (2013) reported the anticancer activity of papaya in CIB Tech JPharm Sic. A papaya in vitro thinks about demonstrates that it will treat numerous disease cell line and papaya physiochemical having anticancer exercises. Papaya is rich in compound papain which is viable against growth. Papain separates the fibrin disease cell divider furthermore, protein into the amino corrosive frame. Other than papain, it, moreover, contains lycopene which exceedingly receptive toward oxygen and free radical. Isothiocyanate present in Papaya is powerful against lung, pancreas and prostate cancer. These chemicals fit of restraining both arrangement and improvement of disease cell.

\section{Antibacterial and wound healing effect of C. papaya [38-41]}

Dawkins et al. have distributed an article on the antibacterial development of $C$. papaya natural product remove against fundamental damage life shapes in the West Indian Medical Journal. They reported seed isolates from the organic product showed obstruction of bacterial development against Bacillus cereus, Escherichia coli, Streptococcus faecalis, Staphylococcus aureus, Proteus vulgaris, and Shigella flexneri. This examination prescribes that $C$. papaya has antibacterial effects that could be profitable in treating perpetual skin ulcers to advance healing. Islam et al. have reported antibacterial activity of the latex of papaya against Bacillus subtilis, E. coli, Agrobacterium sp., and Rhizobium sp. in Asian Journal of Pharmaceutical and Clinical Research.

\section{Antifertility activity [42,43]}

Poharkar et al. revealed that the counter fruitfulness impacts of C. papaya were analyzed by bolstering grown-up and pregnant rodent with various parts of the natural product in the journal herb med toxicology. No endeavor was made to forcibly feed the creature, and the outcome showed that the unripe fruit interfered with the estrous cycle and instigated fetus removal. This impact vanished as the organic product wound up stale or over riped. Chloroform concentrate of C. papaya seeds initiated long haul azoospermia in drowsiness monkey. Papaya additionally demonstrated the counter implantation and abortifacient effect.

\section{Antisickling activity [44-47]}

Mojisola et al. reported antisickling properties of $C$. papaya fruit pulp in refined water, methanol, and chloroform utilizing sodium metabisulfite in Journal of Natural product. Sickle cell sickness comes about because of a transformation in hemoglobin inside the red platelets, where a glutamic acid at sixth position is replaced by valine.

\section{Hepatoprotective effect [48-50]}

Sadeque et al. have revealed the hepato cautious impacts of dried natural products of papaya against carbon tetrachloride prompted hepatotoxicity and it contrasted and that of Vitamin-E. The outcomes affirmed that $C$. papaya and Vitamin E exhibited gigantic hepato security against CCl4 instigated hepatotoxicity, anyway C. papaya demonstrated more tremendous changes in alkaline phosphatase level than Vitamin E. Rajkapoor et al. reported the effect of $C$. papaya on hepatotoxicity in the biological and pharmaceutical bulletin. The ethanol and aqueous extracts of C. papaya showed remarkable hepatoprotective activity against CCl4 induced hepatotoxicity.

\section{Antineoplastic activity $[17,51,52]$}

Praveena et al. reported antineoplastic activity of hydroethanolic concentrate of unripe fruit of papaya utilizing animal model in Asian Journal of Pharmaceutical and Clinical Research. This examination was embraced to screen the effect of administration of different measurements of a hydroethanolic concentrate of the unripe product of papaya against Dalton's ascitic lymphoma (DAL) in Swiss albino mice. In this examination, hydroethanolic concentrate of papaya indicated significant antitumor activity against DAL cell line induced malignant ascites tumor animals.

Antioxidant and Anticancer activities of Hexane fraction from papaya male flower [53-59]

Sianipar et al. reported antioxidant and anticancer activities of hexane fraction from papaya male flower in Asian Journal of Pharmaceutical and Clinical Research. The antioxidant activity was completed utilizing the $\alpha, \alpha$-diphenyl- $\beta$ - picrylhydrazyl technique and the anticancer potential movement was completed utilizing 3-(4,5-dimethythiazol-. 
Table 2: Therapeutic uses of papaya [78]

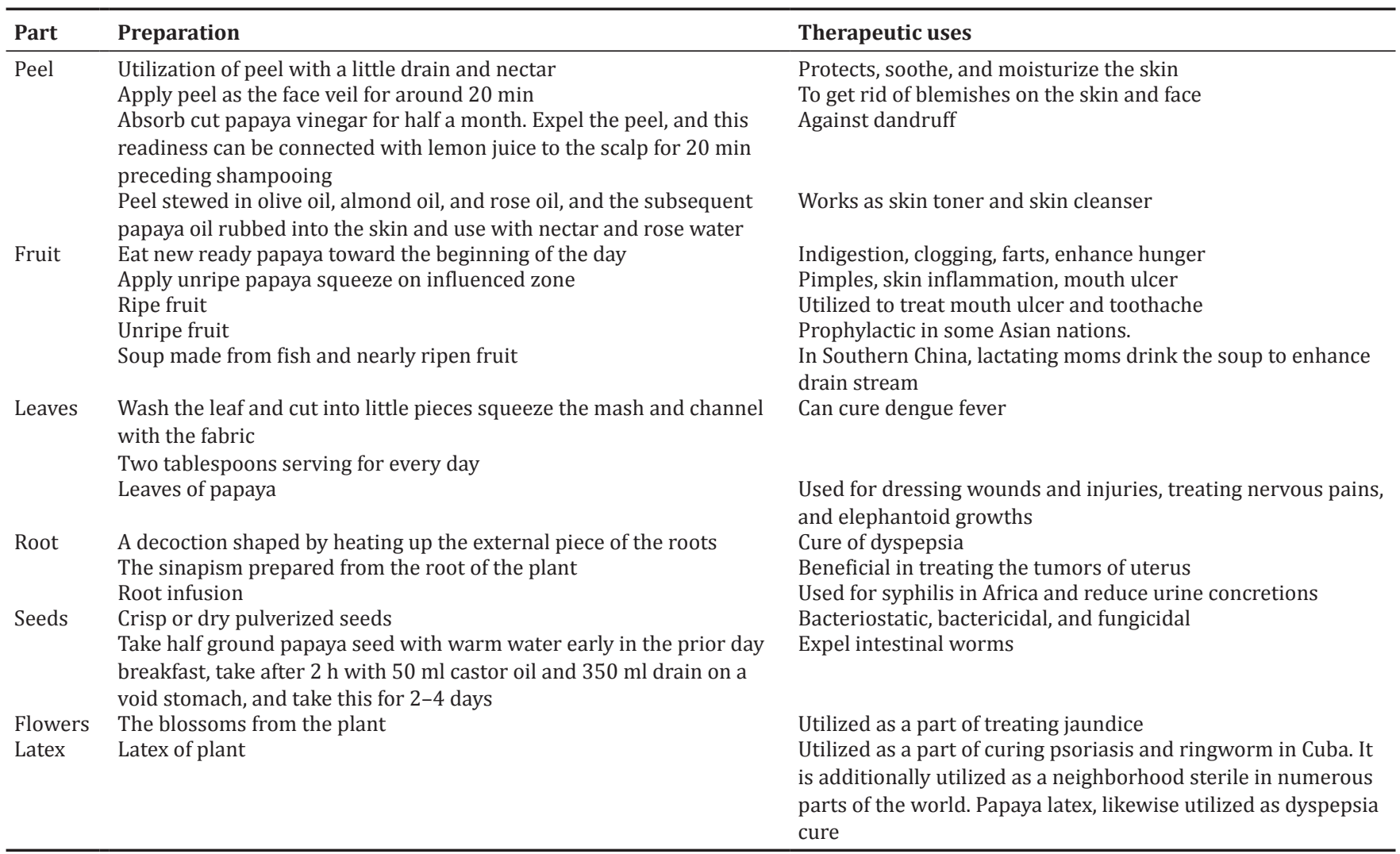

Table 3: Some restorative employments of papaya plant as specified in antiquated Ayurveda literature [79,80]

\begin{tabular}{|c|c|}
\hline Parts & Medicinal aid \\
\hline Latex & $\begin{array}{l}\text { Anthelmintic soothes dyspepsia, cure looseness of } \\
\text { the bowels, agony of consumes and topical utilize, } \\
\text { draining hemorrhoids, stomachic, whooping hack }\end{array}$ \\
\hline Ripe Fruits & $\begin{array}{l}\text { Stomachic, stomach related, carminative, diuretic, } \\
\text { looseness of the bowels and interminable the runs, } \\
\text { expectorant, calming and tonic, eases stoutness, } \\
\text { draining heaps, and injuries of the urinary tract }\end{array}$ \\
\hline Unripe fruit & $\begin{array}{l}\text { Purgative, diuretic, dried juice decreases developed } \\
\text { spleen and liver, utilized as a part of snakebite to } \\
\text { evacuate harm, abortifacient, and antibacterial action }\end{array}$ \\
\hline Seeds & $\begin{array}{l}\text { Carminative, emmenagogue, vermifuge, } \\
\text { abortifacient, counter aggravation, as glue in the } \\
\text { treatment of ringworm and psoriasis, antifertility } \\
\text { operators in guys. }\end{array}$ \\
\hline Seed Juice & Draining heaps and amplified liver and spleen \\
\hline Root & $\begin{array}{l}\text { Abortifacient, diuretic, checking unpredictable } \\
\text { seeping from the uterus, heaps, antifungal movement }\end{array}$ \\
\hline Leaves & $\begin{array}{l}\text { Youthful leaves as vegetable, jaundice (fine glue), } \\
\text { urinary protestations and gonorrhea (implantation), } \\
\text { dressing wounds (crisp leaves), antibacterial } \\
\text { action, vermifuge in colic, fever, beriberi, fetus } \\
\text { removal (imbuement), and asthma (smoke) }\end{array}$ \\
\hline Flowers & $\begin{array}{l}\text { Jaundice, emmenagogue, febrifuge, and pectoral } \\
\text { properties }\end{array}$ \\
\hline Stem bark & $\begin{array}{l}\text { Jaundice, hostile to hemolytic action, sore } \\
\text { teeth (inward bark), against parasitic action }\end{array}$ \\
\hline
\end{tabular}

2-yl)-2,5-diphenyl tetrazolium bromide examines to check the cytotoxic movement on WiDr (colon malignancy cell) and Vero cell (typical cell). Phytochemical screening of the hexane portion from the male blossom of papaya hints at solid triterpenoids and steroids, while the $\mathrm{IC}_{50}$ of cancer prevention agent esteem was $100.81 \pm 1.180 \mu \mathrm{g} / \mathrm{ml}$ cytotoxic impact demonstrates that the hexane portion of papaya male blossom had selectivity to WiDr cell.

\section{Antimicrobial activity of C. papaya [60-64]}

Baskaran et al. assessed the subjective examination of phytochemicals and antimicrobial action of different dissolvable concentrates of C. papaya. The antimicrobial exercises of distinctive dissolvable concentrates of $C$. papaya were tried against the Gram-positive and Gram-negative bacterial strains and growth by watching the zone of a hindrance. The Gram-positive microorganisms utilized as a part of the test were $S$. aureus, B. cereus, and Micrococcus luteus, and the Gramnegative microorganisms were E. coli, and Klebsiella pneumoniae, and the fungus used in the test were Aspergillus niger, A.flavus, C.albicans, Candida tropicalis, Cryptococcus neoformans and Candida kefyr.

Sumathi detailed (2014) phytochemical investigation and in vitro antimicrobial action of fluid and dissolvable concentrates of C. papaya against clinical pathogens in Int J Adv Res Biol Science. The dried powdered plant material is subjected to dissolvable extraction utilizing the solvents chilly water, high temperature water, and ethanol. Antimicrobial measure of plant remove against clinical segregates by AWD examines. Just the leaf separates demonstrated inhibitory impact against $C$. albicans, though stem and root extricates were ineffectual. Among the leaf, stem, and root separates, the leaf remove is found to display more antimicrobial movement than the stem and root.

\section{Anti-HIV activity of C. papaya [2,65-76]}

Rashed et al. (2013) proclaimed phytochemical screening of the polar concentrates of $C$. papaya Linn and the evaluation of the anti-HIV-1 advancement in J Appl Ind Sci. The methanol and watery concentrates of C. papaya were striven for their against HIV-1 activity using the syncytia advancement test. The outcomes have shown that $C$. papaya methanol and fluid concentrates have quiet limit as debilitating to HIV-1 directors. 
Table 4: Synthetic segments distinguished from the leaf concentrates of $C$. papaya [81]

\begin{tabular}{llll}
\hline Sl No. & Synthetic segments & $\begin{array}{c}\text { Molecular } \\
\text { weight }\end{array}$ & $\begin{array}{c}\text { Molecular } \\
\text { formula }\end{array}$ \\
\hline 1 & Decylene & 140 & $\mathrm{C}_{10} \mathrm{H}_{2} \mathrm{O}$ \\
2 & Trans-Geranylacetone & 194 & $\mathrm{C}_{13} \mathrm{H}_{22} \mathrm{O}$ \\
3 & Methyl tridecanoate & 228 & $\mathrm{C}_{14} \mathrm{H}_{28} \mathrm{O}_{2}$ \\
4 & Palmitic acid & 256 & $\mathrm{C}_{16} \mathrm{H}_{32} \mathrm{O}_{2}$ \\
5 & Methyl tetradecanoate & 242 & $\mathrm{C}_{15} \mathrm{H}_{30} \mathrm{O}_{2}$ \\
6 & Myristic acid & 228 & $\mathrm{C}_{14} \mathrm{H}_{28} \mathrm{O}_{2}$ \\
7 & Methyl palmitate & 270 & $\mathrm{C}_{17} \mathrm{H}_{34} \mathrm{O}_{2}$ \\
8 & Hexadecanoic acid & 256 & $\mathrm{C}_{16} \mathrm{H}_{32} \mathrm{O}_{2}$ \\
9 & Methyllinolelaidate & 294 & $\mathrm{C}_{19} \mathrm{H}_{34} \mathrm{O}_{2}$ \\
10 & Methyl cis-6-octadecenoate & 296 & $\mathrm{C}_{19} \mathrm{H}_{36} \mathrm{O}_{2}$ \\
11 & Stearic acid, methyl ester & 298 & $\mathrm{C}_{19} \mathrm{H}_{38} \mathrm{O}_{2}$ \\
12 & Oleic acid & 282 & $\mathrm{C}_{18} \mathrm{H}_{34} \mathrm{O}_{2}$ \\
13 & Stearic acid & 284 & $\mathrm{C}_{18} \mathrm{H}_{36} \mathrm{O}_{2}$ \\
14 & 15-Tetracosenoic acid & 380 & $\mathrm{C}_{25} \mathrm{H}_{48} \mathrm{O}_{2}$ \\
15 & Methyl heptacosanoate & 424 & $\mathrm{C}_{28} \mathrm{H}_{56} \mathrm{O}_{2}$ \\
16 & trans-13-Docosenoic acid & 338 & $\mathrm{C}_{22} \mathrm{H}_{42} \mathrm{O}_{2}$ \\
17 & Methyl erucate & 352 & $\mathrm{C}_{23} \mathrm{H}_{44} \mathrm{O}_{2}$ \\
18 & Methyl behenate & 354 & $\mathrm{C}_{23} \mathrm{H}_{46} \mathrm{O}_{2}$ \\
19 & Heneicosanoic acid, methyl & 340 & $\mathrm{C}_{22} \mathrm{H}_{44} \mathrm{O}_{2}$ \\
& ester & & $\mathrm{C}_{30} \mathrm{H}_{50}$ \\
\hline 20 & Farnesyl cyanide & 410 &
\end{tabular}

C. papaya: Carica papaya

\section{Nutritional value of papaya plant}

Papaya is a sensibly surveyed standard thing has high nutritive respect. It is low in calories and rich in normal vitamins and minerals. The relative low calories content effects this most needed to ordinary thing for hefty individuals who are into weight diminish organization. The nutritional values and the chemical constituents of papaya plant were tabulated in Table. 3 and Table.4 respectively.

\section{CONCLUSION}

Papaya plant is fundamentally utilized as the food ingredient all through the world in light of its foods grown from the ground nutritive esteem. From the above examinations about the papaya plant exhibits that its leaves, seeds, roots, blossoms, ready, and unripe fruit juices were used as a customary drug. By the conventional cases, papaya is a capable pharmaceutical. Critical measure of work has been done on the biological activities and the uses of substance constituents, consequently broad examination on its pharmacodynamics, energy, appropriate institutionalization, clinical trials are expected to abuse the healing utility to fight diverse disorders.

\section{ACKNOWLEDGMENTS}

We sincerely thank the SRM Institute of Science and Technology, Chennai, for their continuous support and cooperation to carry out this work.

\section{AUTHOR'S CONTRIBUTIONS}

All authors contributed equally to this work.

\section{CONFLICTS OF INTEREST}

The authors have none to declare.

\section{REFERENCES}

1. Oliver-Bever B. Medicinal Plants in Tropical West Africa. Cambridge: Cambridge University Press; 1986. p. 161.

2. Yogiraj V, Goyal PK, Chauhan CS, Goyal A, Vyas B. Carica papaya Linn: An overview. Int J Herb Med 2014;2:1-8.

3. Ahmad N, Fazal H, Ayaz M, Abbasi BH, Mohammad I, Fazal L, et al. Dengue fever treatment with Carica papaya leaves extracts. Asian Pac J Trop Biomed 2011;1:330-3

4. Charan J, Saxena D, Goyal JP, Yasobant S. Efficacy and safety of
Carica papaya leaf extract in the dengue: A systematic review and meta-analysis. Int J Appl Basic Med Res 2016;6:249-54.

5. Patil S, Shetty S, Bhide R, Narayanan S. Evaluation of platelet augmentation activity of Carica papaya leaf aqueous extract in rats. J Pharmacog Phytochem 2013;1:227-32.

6. Pigli RK, Runja C. Medicinal plants used in dengue treatment. Int J Chem Nat Sci 2014;2:70-6.

7. Hettige S. Salutary effects of Carica papaya leaf extract in dengue fever patients-a pilot study. Sri Lankan Fam Physician 2008;29:17-9.

8. Yunita F, Hanani E, Kristianto J. The effect of Carica papaya L. Leaves extract capsules on platelets count and hematocrit level in dengue fever patient. Int J Med Aromat Plants 2012;2:573-8.

9. Manohar PR. Papaya, dengue fever and ayurveda. Anc Sci Life 2013;32:131-3.

10. Senthilvel P, Lavanya P, Kumar KM, Swetha R, Anitha P, Bag S, et al. Flavonoid from Carica papaya inhibits NS2B-NS3 protease and prevents dengue 2 viral assembly. Bioinformation 2013;9:889-95.

11. Sarala N, Paknikar S. Papaya extract to treat dengue: A novel therapeutic option? Ann Med Health Sci Res 2014;4:320-4.

12. Dharmarathna SL, Wickramasinghe S, Waduge RN, Rajapakse RP, Kularatne SA. Does Carica papaya leaf-extract increase the platelet count? An experimental study in a murine model. Asian Pac J Trop Biomed 2013;3:720-4

13. Kasture PN, Nagabhushan KH, Kumar A. A multi-centric, doubleblind, placebo-controlled, randomized, prospective study to evaluate the efficacy and safety of Carica papaya leaf extract, as empirical therapy for thrombocytopenia associated with dengue fever. J Assoc Physicians India 2016;64:15-20.

14. Ikpeme EV, Ekaluo UB, Kooffreh ME, Udensi O. Phytochemistry and heamatological potential of ethanol seed leaf and pulp extracts of Carica papaya (Linn.). Pak J Biol Sci 2011;14:408-11.

15. Jaiswal P, Kumar P, Singh VK, Singh DK. Carica papaya Linn: A potential source for various health problems. J Pharm Res 2010;3:998-1003.

16. Kumar KS, Bhowmik D. Traditional and medicinal uses of banana. J Pharm Phytochem 2012 1;1:51-63.

17. Sasidharan S, Sumathi V, Jegathambigai NR, Latha LY. Antihyperglycaemic effects of ethanol extracts of Carica papaya and Pandanus amaryfollius leaf in streptozotocin-induced diabetic mice. Nat Prod Res 2011;25:1982-7.

18. Maniyar Y, Bhixavatimath P. Antihyperglycemic and hypolipidemic activities of aqueous extract of Carica papaya linn. Leaves in alloxaninduced diabetic rats. J Ayurveda Integr Med 2012;3:70-4

19. Oloyede OI. Chemical profile of unripe pulp of Carica papaya. Pak J Nutr 2005;4:379-81.

20. Mentreddy SR, Mohamed AI, Rimando AM. Medicinal plants with hypoglycemic/anti-hyperglycemic properties: A review. Proc Assoc Adv Ind Crop Conf 2005;20:341-53.

21. Muss C, Mosgoeller W, Endler T. Papaya preparation in digestive disorders. Biogenic Amines 2012;26:1-17.

22. Okeniyi JA, Ogunlesi TA, Oyelami OA, Adeyemi LA. Effectiveness of dried Carica papaya seeds against human intestinal parasitosis: A pilot study. J Med Food 2007;10:194-6.

23. Ayoola PB, Adeyeye A. Phytochemical and nutrient evaluation of Carica papaya leaves. Int J Recent Res Appl Stud 2010;5:325-8.

24. Alanís AD, Calzada F, Cervantes JA, Torres J, Ceballos GM. Antibacterial properties of some plants used in Mexican traditional medicine for the treatment of gastrointestinal disorders. J Ethnopharmacol 2005;100:153-7.

25. Calzada F, Yépez-Mulia L, Aguilar A. In vitro susceptibility of Entamoeba histolytica and giardia lamblia to plants used in Mexican traditional medicine for the treatment of gastrointestinal disorders. J Ethnopharmacol 2006;108:367-70.

26. Chávez-Quintal P, González-Flores T, Rodríguez-Buenfil I, GallegosTintoré S. Antifungal activity in ethanolic extracts of Carica papaya L. Cv. Maradol leaves and seeds. Indian J Microbiol 2011;51:54-60.

27. Singh O, Ali M. Phytochemical and antifungal profiles of the seeds of Carica papaya L. Indian J Pharm Sci 2011;73:447-51.

28. Baskaran C, Velu S, Kumaran K. The efficacy of Carica papaya leaf extract on some bacterial and a fungal strain by well diffusion method. Asian Pac J Trop Dis 2012;2:S658-62.

29. Kujumgiev A, Tsvetkova I, Serkedjieva Y, Bankova V, Christov R, Popov S, et al. Antibacterial, antifungal and antiviral activity of propolis of different geographic origin. J Ethnopharmacol 1999;64:235-40.

30. Pattnaik S, Subramanyam VR, Bapaji M, Kole CR. Antibacterial and antifungal activity of aromatic constituents of essential oils. Microbios 1997;89:39-46. 
31. Adebiyi A, Adaikan PG, Prasad RN. Papaya (Carica papaya) consumption is unsafe in pregnancy: Fact or fable? Scientific evaluation of a common belief in some parts of Asia using a rat model. Br J Nutr 2002;88:199-203.

32. Bose BC, Saifi AQ, Vijayvargiya R, Bhagwat AW. Pharmacological study of Carica papaya seeds with special reference to its anthelmintic action. Preliminary report. Indian J Med Sci 1961;15:888-92.

33. Satrija F, Nansen P, Murtini S, He S. Anthelmintic activity of papaya latex against patent Heligmosomoides polygyrus infections in mice. J Ethnopharmacol 1995;48:161-4.

34. Kanthal LK, Mondal P, Somnath DE, Jana S, Aneela S, Satyavathi K. Anthelmintic activity of Carica papaya Latex using Pheritima Posthuma. Int J Life Sci Pharm Res 2012;2:10-2.

35. Otsuki N, Dang NH, Kumagai E, Kondo A, Iwata S, Morimoto C, et al. Aqueous extract of Carica papaya leaves exhibits anti-tumor activity and immunomodulatory effects. J Ethnopharmacol 2010;127:760-7.

36. Nguyen TT, Shaw PN, Parat MO, Hewavitharana AK. Anticancer activity of Carica papaya: Areview. Mol Nutr Food Res 2013;57:153-64.

37. Fauziya S, Krishnamurthy R. Papaya source material for anticancer. CIB Tech J Pharm Sci 2013;2:25-34.

38. Dawkins G, Hewitt H, Wint Y, Obiefuna PC, Wint B. Antibacterial effects of Carica papaya fruit on common wound organisms. West Indian Med J 2003;52:290-2

39. Romasi EF, Karina J, Parhusip AJ. Antibacterial activity of Papaya leaf extracts against pathogenic bacteria. Makara Teknologi 2011;15:173-7.

40. Islam A, Al-Mamun MA, Parvin S, Meh S. Evaluation of antibacterial activity of Latex of Caricacea. Asian J Pharm Cli Res 2015;8:308-11.

41. Nayak SB, Pinto Pereira L, Maharaj D. Wound healing activity of Carica papaya L. In experimentally induced diabetic rats. Indian J Exp Biol 2007;45:739-43.

42. Poharkar RD, Saraswat RK, Kotkar S. Survey of plants having antifertility activity from Western Ghat area of Maharashtra state. J Herb Med Toxicol 2010;4:71-5.

43. Lohiya NK, Goyal RB, Jayaprakash D, Ansari AS, Sharma S. Antifertility effects of aqueous extract of Carica papaya seeds in male rats. Planta Med 1994;60:400-4.

44. Mojisola OC, Adebolu EA, Alani DM. Antisickling properties of Carica papaya Linn. J Nat Prod 2008;1:56-66.

45. Imaga NO, Gbenle GO, Okochi VI, Akanbi SO, Edeoghon SO, Oigbochie V, et al. Antisickling property of Carica papaya leaf extract. Afr J Biochem Res 2009;3:102-6.

46. Okpuzor J, Adebesin O, Ogbunugafor H, Amadi I. The potential of medicinal plants in sickle cell disease control: A review. Int J Biomed Health Sci 2008;4:47-55.

47. Karunamoorthi K, Kim HM, Jegajeevanram K, Xavier J, Vijayalakshmi J. Papaya: A gifted nutraceutical plant a critical review of recent human health research. TANG 2014;4:21-7.

48. Sadeque MZ, Begum ZA, Umar BU, Ferdous AH, Sultana S, Uddin MK. Comparative efficancy of dried fruits of Carica papaya Linn. And Vitamin E on preventing hepatotoxicity in rats. Faridpur Med Coll J 2012;7:29-32.

49. Rajkapoor B, Jayakar B, Kavimani S. Effect of Carica papaya on hepatotoxicity. Biol Pharm Bull 2002;25:1645-6.

50. Adeneye AA, Olagunju JA, Banjo AF, Abdul SF, Sanusi OA, Sanni OO, et al. The aqueous seed extract of Carica papaya Linn. Prevents carbon tetrachloride induced hepatotoxicity in rats. Int J Appl Res Nat Prod 2009;2:19-32

51. Ranasinghe $\mathrm{P}$, Ranasinghe $\mathrm{P}$, Abeysekera WP, Premakumara GA, Perera YS, Gurugama P, et al. In vitro erythrocyte membrane stabilization properties of Carica papaya L. Leaf extracts. Pharmacognosy Res 2012;4:196-202.

52. Praveena P, Jethinlalkhosh JP, Doss VA. Pharmacological evaluation of antineoplastic activity of hydroethanolic extract of unripe fruit of Carica papaya Linn using animal model. Asian J Pharm Clin Res2017;10:179-81

53. Sianipar MP, Suwarso E, Rosidah R. Antioxidant and anticancer activities of hexane fraction from Carica papaya L. Male flower. Asian J Pharm Clin Res 2018;11:81-3.

54. Gogna N, Hamid N, Dorai K. Metabolomic profiling of the phytomedicinal constituents of Carica papaya L. Leaves and seeds by $1 \mathrm{H}$ NMR spectroscopy and multivariate statistical analysis. J Pharm Biomed Anal 2015;115:74-85.

55. Akhter T, Khan MI, Eva EO. Comparative evaluation of platelet augmentation activity of Carica papaya leaf juice and hydrocortisone in thrombocytopenic rats. Bangladesh J Physiol Pharm 2015;30:32-40.

56. Mehdipour S, Yasa N, Dehghan G, Khorasani R, Mohammadirad A, Rahimi R, et al. Antioxidant potentials of Iranian Carica papaya juice in vitro and in vivo are comparable to $\alpha$-tocopherol. Phytother Res 2006;20:591-4.

57. Vuong QV, Hirun S, Roach PD, Bowyer MC, Phillips PA, Scarlett CJ. Effect of extraction conditions on total phenolic compounds and antioxidant activities of Carica papaya leaf aqueous extracts. J Herb Med 2013;3:104-11

58. Maisarah AM, Amira BN, Asmah R, Fauziah O. Antioxidant analysis of different parts of Carica papaya. Int Food Res J 2013;20:1043-8.

59. Rahmat A, Bakar MF, Faezah N, Hambali Z. The effects of consumption of guava (Psidium guajava) or papaya (Carica papaya) on total antioxidant and lipid profile in normal male youth. Asia Pac J Clin Nutr 2004;13:S106.

60. Baskaran C, Bai VR, Velu S, Kumaran K. The efficacy of Carica papaya leaf extract on some bacterial and fungal strain by well diffusion method. Asian Pac J Trop Dis 2012;2012:347-9.

61. Osato JA, Santiago LA, Remo GM, Cuadra MS, Mori A. Antimicrobial and antioxidant activities of unripe papaya. Life Sci 1993;53:1383-9.

62. Sumathi R. Phytochemical analysis and in vitro antimicrobial activity of aqueous and solvent extracts of Carica papaya against clinical pathogens. Int J Adv Res Biol Sci 2014;1:73-7.

63. Anibijuwon II, Udeze AO. Antimicrobial activity of Carica papaya on some pathogenic organisms of clinical origin from South-Western Nigeria. Ethnobotanical Leaf 2009;4:850-64.

64. Doughari JH, Elmahmood AM, Manzara S. Studies on the antibacterial activity of root extracts of Carica papaya L. Afr J Microbiol Res 2007;1:37-41.

65. Rashed K, Luo MT, Zhang LT, Zheng YT. Phytochemical screening of the polar extracts of Carica papaya Linn and the evaluation of the AntiHIV-1 activity. J Appl Ind Sci 2013;1:49-53.

66. Mbosso Teinkela JE, Assob Nguedia JC, Meyer F, Vouffo Donfack E, Lenta Ndjakou B, Ngouela $\mathrm{S}$, et al. In vitro antimicrobial and antiproliferative activities of plant extracts from Spathodea campanulata, Ficus bubu, and Carica papaya. Pharm Biol 2016;54:1086-95.

67. Bhadane V, Belemker S, Mali B. The nature's potential multipurpose gift-papaya (Carica papaya Linn.): A complete overview. Asian J Pharm Res Dev 2014;2:75-82.

68. Tewari BB, Gomathinayagam S. A critical review on Ocimum tenuflorum, Carica papaya and Syzygium cumini: The medicinal flora of Guyana. Revista Boliviana de Química2014;31:28-41.

69. Maroyi A. Alternative medicines for HIV/AIDS in resource-poor settings: Insight from traditional medicines use in sub-Saharan Africa. Trop J Pharm Res 2014;13:1527-36.

70. Ahmad F. Chemical studies on biologically active natural product from medicinal plants in Sabah. Borneo Sci 2000;7:55-62.

71. Abu A, Uchendu C, Ofukwu R. Sperm immobilization properties of aqueous ethanolic extract of Hymenocardia acida stems bark. Maced J Med Sci 2011;4:261-4.

72. Chidozie VN, Adoga GI. Potentiating effect of aqueous leaf extract of Anogeissus leiocarpus on Carica papaya aqueous leaf extract and Mangifera indica aqueous stem bark extract-A herbal product used against typhoid fever in Nigeria. Int J Curr Microbiol App Sci 2014;3:1046-62.

73. Pathy K. The Influenza a virus subtypes H1N1, H1N2 and H3N2, HDFx: A novel immunomodulatory and potential fighter against cytokine storms in viral flu infections-Carica papaya Linn. J Clin Nurs Res 2017;1:30.

74. Prakash D, Upadhyay G, Singh BN, Dhakarey R, Kumar S, Singh KK. Free-radicall scavenging activities of Himalayan rhododendrons. Curr Sci 2007;25:526-32

75. Ramdhan B, Chikmawati T, Waluyo EB. Ethnomedical herb from Cikondang indigenous village, district Bandung West Java Indonesia. J Biodivers Environ Sci (JBES) 2015;6:277-88.

76. Gerencer M, Turecek PL, Kistner O, Mitterer A, Savidis-Dacho H, Barrett NP, et al. In vitro and in vivo anti-retroviral activity of the substance purified from the aqueous extract of Chelidonium majus L. Antiviral Res 2006;72:153-6.

77. Mendows J. Sarasota Herald, Tribune, Food Section. Available from: http//www.sarasota.extension.ulf.edu/fcs/FFFindex.html; http//www. bawarchi com/health/index.html; http//www.specialtyproduct.com. [Last accessed on 1995 Sep 25].

78. Aravind. G, Debjit B, Duraivel S, Harish G. Traditional and medicinal uses of Carica papaya. J Med Plants Stud 2013;1:7-15.

79. Nadkarni KM. Indian material medica. Bombay 1954;1:273-7.

80. Sala AV. Indian Medicinal Plants and Compendium of 500 Species. Vol. 1. Delhi, India: University Bookstore; 2005. p. 383-4

81. Oche O, Rosemary A, John O, Chidi E, Rebecca SM, Vincent UA. Chemical constituents and nutrient composition of Carica papaya and Vernonia amygdalina Leaf extracts. J Complement Altern Med Res 2017;2:1-8. 